\title{
Imposex in Stramonita haemastoma from coastal sites of Cartagena, Colombia
}

\author{
L. Sierra-Marquez ${ }^{a}$, J. Sierra-Marquez ${ }^{a}$, J. De la Rosa ${ }^{b}$ and J. Olivero-Verbel ${ }^{\text {* }}$ \\ ${ }^{a}$ Environmental and Computational Chemistry Group, School of Pharmaceutical Sciences, University of Cartagena, \\ Zaragocilla Campus, 130015, Cartagena, Colombia \\ ${ }^{\mathrm{b}}$ Center for Research in Sustainable Chemistry - CIQSO, University of Huelva, Campus de El Carmen, Robert H. Grubbs \\ Building, s/n, E-21071, Huelva, Spain \\ *e-mail: joliverov@unicartagena.edu.co
}

Received: December 10, 2016 - Accepted: January 31, 2017 - Distributed: October 31, 2018

(With 7 figures)

\begin{abstract}
Imposex is the development of male sexual characteristics caused by the toxic effects of some chemicals that acts as an endocrinal disruptor. Antifouling paints contain these chemicals. Cartagena lacks studies to indicate the extent of imposex in its coastal waters. The aim of this study was to determine the prevalence of imposex in the gastropod Stramonita haemastoma in Cartagena, Colombia. Specimens were collected during 2013 from locations of high and low influence of port activity. Morphometric measurements and the frequency of the occurrence of imposex were registered. The comparison among morphometric variables showed statistically significant differences between the two sites studied. Furthermore, the females of the S. haemastoma species presented an imposex frequency of 93.1\% in Birds' Island, Cartagena Bay, compared to $31.8 \%$ in La Bocana. The relative penis size index or RPLI (10.145 and 3.231) and vas deferens sequence index or VDSI (2.83 and 1.16), showed possible contamination by organotin compounds in both places.
\end{abstract}

Keywords: imposex, bioaccumulation, boat paint, organotin compounds, penis development, toxicity.

\section{Imposex em Stramonita haemastoma em locais costeiros de Cartagena, Colômbia}

\section{Resumo}

Imposex é o desenvolvimento de características sexuais masculinas causadas por poluentes tóxicos de alguns produtos químicos que atuam como desreguladores endócrinos. Tintas anti-incrustantes são as que contêm estes produtos químicos. Cartagena carece de estudos para indicar a extensão do imposex nas suas águas costeiras. O objetivo deste estudo foi determinar a prevalência de imposex no gastrópode Stramonita haemastoma em Cartagena, Colômbia. Os espécimes foram coletados durante 2013 de locais de alta e baixa influência da atividade portuária. Foram registradas as medidas morfométricas e a frequência da ocorrência do imposex. A comparação entre as variáveis morfométricas mostrou diferenças estatisticamente significantes entre os dois locais estudados. Além disso, as fêmeas da espécie S. haemastoma apresentaram uma frequência de imposex de 93,1\% na Ilha das Aves, Baía das Cartagena, em comparação com 31,8\% em La Bocana. O índice do comprimento relativo do pênis ou RPLI $(10,145$ e 3,231) e o índice da sequência do vaso deferente ou VDSI $(2,83$ e 1,16), mostraram possível contaminação por compostos organoestânicos em ambos os locais.

Palavras-chave: imposex, bioacumulação, pintura para barco, compostos organoestânicos, desenvolvimento do pênis, toxicidade.

\section{Introduction}

The coastal areas of a country play a key role in its ecological, social, and economic development. However, there are always several issues that alter the balance of coastal dynamics, causing environmental impacts, largely motivated by conflicts of interest among uses such as recreation, port activity, and mining (Johnson-Restrepo et al., 2008; Gavio et al., 2010). Human impacts on nature, combined with natural processes, have triggered a largely ignored emergent phenomenon on organisms, such as changes in reproductive function derived from exposure to endocrine disruptors (Petro et al., 2012; Giusti and Joaquim-Justo, 2013; Halem et al., 2014). These studies point to the need for further research to determine the extent of which the human population may be affected. 
Aquatic organisms adhering to the surface of vessels increase frictional resistance, fuel consumption and reduce their speed (Bai et al., 2013). The solution to this problem arrived with the development of antifouling biocide paints, chemicals widely used to prevent the adhesion of organisms to the vessels. In the late 1950s, new properties of organotin compounds were discovered, particularly for tributyltin (TBT), allowing its use as an agent to avoid the adherence of these organisms (Furdek et al., 2012). TBT was mostly employed in sea-bound vessels (Radke et al., 2012; Zhang et al., 2013); however, two decades later this chemical was associated with imposex, a disorder that involves the imposition of male sexual characteristics on the female reproductive system of some gastropods. Findings such as a penis, vas deferens, and the transformation of the oviduct into a seminal vesicle structure were consequences of specific exposure to these chemicals (Castro et al., 2012). Although TBT has been banned in several places around the world (Verhaegen et al., 2012), in many countries such as in Colombia, there are no restrictions at all. Therefore, as TBT and related chemicals are active at very low concentrations, vessels painted with antifouling agents are a common source of these pollutants in seaports, among other places.

Ships from all over the world frequent Cartagena, and considering this together with a deficiency in national regulation, it became necessary to obtain scientific information that would support a legal basis for preserving environmental heritage and implementing economic and environmentally sustainable activities. For these reasons, the main goal of this study was to diagnose the masculinization of female specimens of S. haemastoma in the marine aquatic environment of Cartagena, possibly resulting from the TBT-related port activities.

\section{Material and Methods}

Sampling locations around the coastal area of the city of Cartagena, Colombia, are shown in Figure 1. This city is a touristic and historical place with 447,857 inhabitants (DANE, 2010). During the year 2013, adult specimens of $S$. haemastoma, a species commonly found in mangrove areas along the North Coast of Colombia, were collected in two areas along the coastal line of the city of Cartagena: The Birds' Island (10²5’16. 26” N, 75’32’31. 23” O), usually used as a port for many small and medium-size vessels; and La Bocana (10²7’20.92” N, 75³0’39.85” O), location with a low frequency of fishing boats (Figure 1). During transportation to the lab, samples were kept in water. Specimens were anesthetized exposing them for $2 \mathrm{~h}$ to $3.5 \% \mathrm{MgCl}_{2}$ dissolved in distilled water in a 1:1 solution with local seawater (Castro et al., 2012). A soft brush was employed to remove sediment and other residues from the shell, washing samples with tap water and finally drying them with an absorbent towel.

Prior to examining individual anatomy, the shell length (SL), width (SW) and thickness (ST) of S. haemastoma were measured to the nearest $0.1 \mathrm{~mm}$ using a vernier/caliper. The total weight (TW) was recorded without removing the shells of the specimen using an electronic balance (OHAUS) to the nearest $\mathrm{mg}$. Tissue samples were carefully extracted and the soft tissue weighted, representing biomass (B).

The sex of each individual was verified under a stereomicroscope (Nikon SMZ 745T) by observing the presence of the prostate gland in males and the albumen and sperm-ingesting capsule glands in females (Gibbs and Bryan, 1987, 1994). After recording the presence of a penis, it was gently straightened and the length was measured to the nearest $0.1 \mathrm{~mm}$ using a caliper. Four criteria were applied to the samples to categorize different states of imposex: The first criterion was the presence of pseudopenis in females. Second,

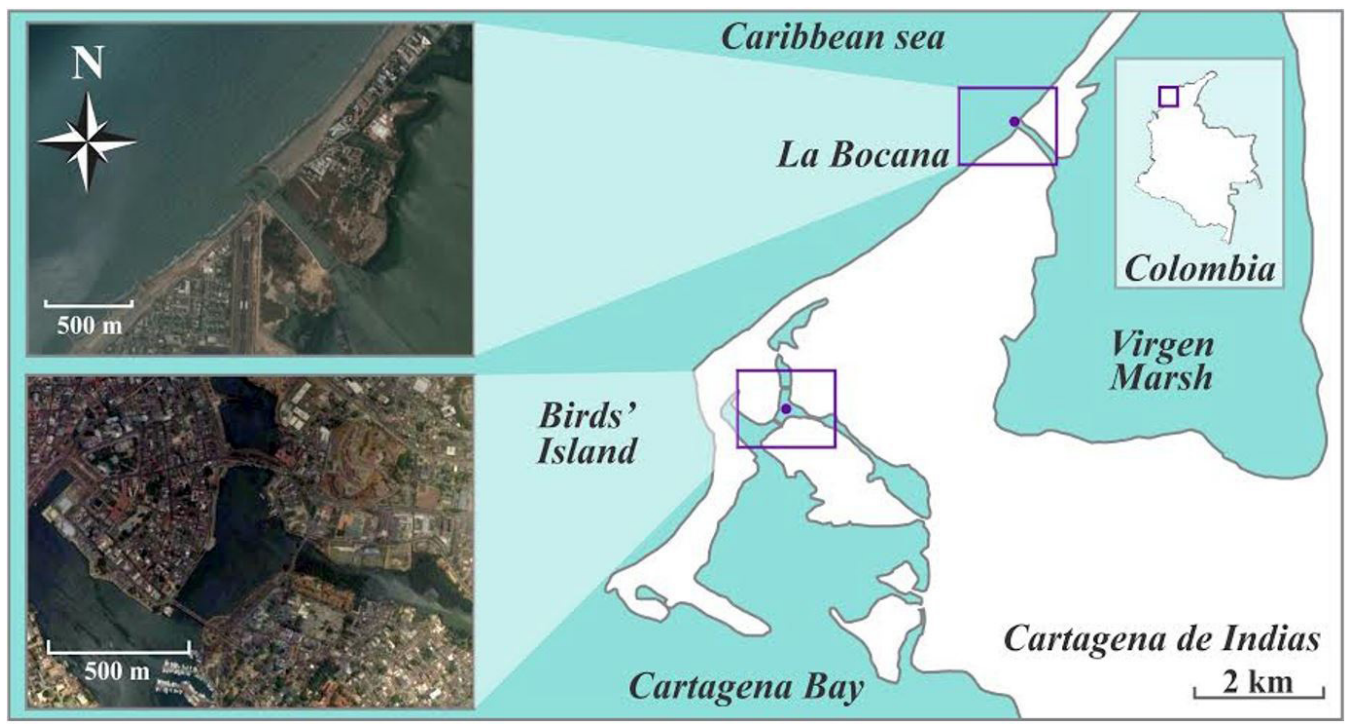

Figure 1. Geographic location of the study area. 
the relative penis length index (RPLI), calculated as the ratio of the mean penis length of imposexed females to the mean penis length of males at each station, multiplied by 100. Third, the relative penis size index (RPSI), obtained in the same manner as the RPLI, but using cubed mean penis lengths to indicate volumes. The final criterion was the vas deferens sequence index (VDSI). This last was determined employing a six-stage scale similar to the classic Gibbs and Bryan (1994) scale for Nucella lapillus, adapted for S. haemastoma (Fernández et al., 2002; Lima et al., 2006).

Room temperature-dried shell samples were crushed and pulverized using standard methods. Eight metals (Cr, Ni, Cu, Zn, As, Cd, Sn and $\mathrm{Pb}$ ) were analyzed on an AGILENT 7700 ICP-MS at the Central Laboratory of the University of Huelva, Spain, following digestion of $0.1 \mathrm{~g}$ in a $\mathrm{HF}+\mathrm{HNO}_{3}(8 \mathrm{~mL}: 3 \mathrm{~mL})$ solution, drying, and a second dissolution in $\mathrm{HNO}_{3}(3 \mathrm{~mL})$ and $\mathrm{HCl}(3 \mathrm{~mL})$. All the acids used were High Purity Acid Suprapur ${ }^{\circledR}$, Merck. Three multi-elemental solutions $\operatorname{Spec}^{\circledR} 1$ (rare earth elements, $\mathrm{REE}), \mathrm{Spec}^{\circledR} 2$ (alkalis, earth alkalis, and metals) and $\mathrm{Spec}^{\circledR}$ $4(\mathrm{Nb})$ were employed to construct an external calibration curve. The lower detection limit (LDL) for most elements in solution was $0.01 \mathrm{ppb}$. The average precision and accuracy for analyzed elements fall in the range of 5-10\%, and were controlled by repeated analysis of the SARM-1 (granite) and SARM-4 (norite) international rock standard of the South Africa Bureau of Standards.

This study presents quantitative data as mean \pm standard error. Mean comparisons between sampling sites were carried out employing a T-test after the evaluation of normality and homogeneity of variance. In the case of imposex prevalence, frequencies were analyzed using Chi-square. The degree of association between morphometric variables was assessed by cluster analysis. In all cases, the significance level was $p<0.05$ and analyses were performed using the statistical package R 3.0.2., and Statgraphics Centurion (Statgraphics Technologies, 2013).

\section{Results}

A total of 110 specimens of $S$. haemastoma were collected ( 60 from Bird's Island and 50 from La Bocana), $54 \%$ males and $46 \%$ females. The average values for each recorded morphometric variable are shown in Table 1. Most morphometric variables (SL, SW, TW and B) were significantly different between sampling sites $(p<0.05)$.

Imposex prevalence in females for sampling sites is presented in Figure 2. It was $93.1 \%$ in female specimens from the Birds' Island and $31.8 \%$ in those from La Bocana. Frequency distribution analysis of specimens with and without imposex showed significant differences $(p<0.05)$ between sampling sites, being the Birds' Island the area of greatest frequency in the onset of this disorder.

The size of the penis in males and pseudo-penis in females with imposex are displayed in Figure 3. Male snails had penis sizes approximately 10 - and 30 -fold greater than imposexed females from Birds' Island and La Bocana, respectively. The RPLI and RPSI indices measured in imposexed females were estimated as a measure of the intensity of imposex, and the results are presented in Table 2.

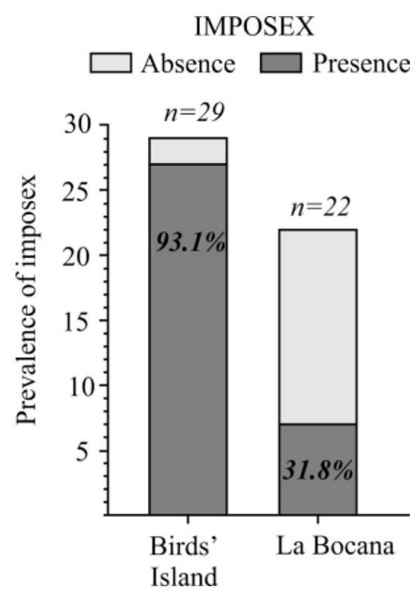

Figure 2. Females with imposex in sampled sites.
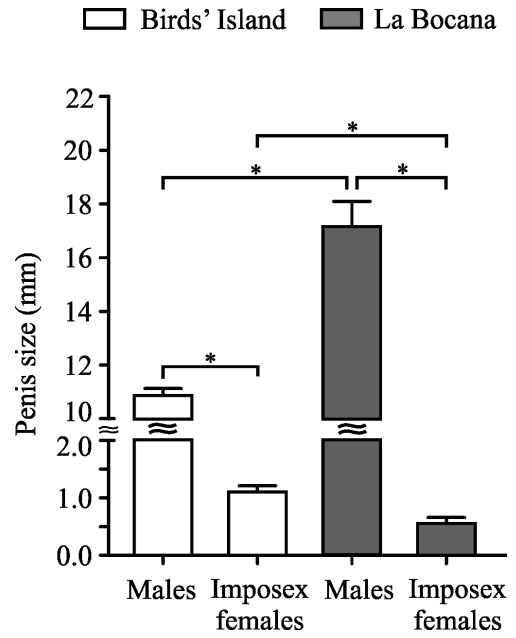

Figure 3. Size of the penis in males and pseudo-penis in females with imposex. *Statistically significant difference between groups $(p<0.05)$.

Table 1. Morphological information of the collected samples.

\begin{tabular}{ccccccccc}
\hline Site & $\mathbf{N}$ & $\mathbf{M}$ & $\mathbf{F}$ & $\mathbf{S L}(\mathbf{c m})$ & $\mathbf{S W}(\mathbf{c m})$ & $\mathbf{S T}(\mathbf{m m})$ & $\mathbf{T W}(\mathbf{g})$ & $\mathbf{B}(\mathbf{g})$ \\
\hline Birds' Island & 60 & 31 & 29 & $2.79 \pm 0.19^{*}$ & $1.87 \pm 0.14^{*}$ & $1.58 \pm 0.34$ & $4.47 \pm 0.97 *$ & $0.77 \pm 1.77^{*}$ \\
La Bocana & 50 & 28 & 22 & $5.01 \pm 0.61$ & $3.03 \pm 0.41$ & $1.62 \pm 0.32$ & $18.73 \pm 7.59$ & $5.29 \pm 2.17$ \\
\hline
\end{tabular}

N: Sample number; M: Male; F: Female; SL (cm); Shell Length; SW (cm); Shell Width; ST (mm); Shell Thickness; TW (g), Total Weight; B (g); Biomass; *Significantly different between sampling sites $(\mathrm{P}<0.05)$. 
The estimated stages of imposex development in female snails from the sampling sites, measured as VDSI values, are presented in Table 3. Females from Birds' Island have the highest levels of imposex (Levels II and IV).

Table 2. RPLI and RPSI indices.

\begin{tabular}{crc}
\hline Location Sampling & RPLI & RPSI \\
\hline Birds' Island & 10.145 & 0.104 \\
La Bocana & 3.231 & 0.003 \\
\hline
\end{tabular}

Photographs of imposexed females showing an imposex level of 2 are depicted in Figure 4.

On the other hand, morphometric variables in groups divided according to the presence or absence of imposex are depicted in Figure 5.

Length and weight of snail specimens were significatively greater in normal females (Figures 5A and 5B). Female specimens with imposex have lower weights than males and normal females. No statistical differences were detected for shells thickness (ST) between analyzed groups (Figure 5C).

Table 3. Level of imposex in specimens from sampling sites.

\begin{tabular}{|c|c|c|c|c|c|c|c|c|c|}
\hline \multicolumn{9}{|c|}{ Stages of imposex development in females (VDSI) } & \multirow{2}{*}{$\begin{array}{c}\text { Total } \\
\text { Females }\end{array}$} \\
\hline Lev & imposex* & $\mathbf{0}$ & I & II & III & IV & $\mathbf{V}$ & VI & \\
\hline \multirow{2}{*}{ Site } & Birds' Island & 2 & 11 & 13 & 0 & 3 & 0 & 0 & 29 \\
\hline & La Bocana & 15 & 7 & 0 & 0 & 0 & 0 & 0 & 22 \\
\hline
\end{tabular}

*Levels of imposex were categorized based on the following stages: I. Beginning of penile formation (papilla); II. Small penis already formed and beginning of formation of the penile duct; III. Female penis less than $1 / 2$ the average length of a male penis at the same sampling station with incomplete vas deferens; IV. Female penis greater than $1 / 2$ the average length of a male penis at the same sampling station with complete vas deferens; V. Total blocking of the vulva; VI. Abortive capsules (Fernández et al., 2002; Lima et al., 2006).
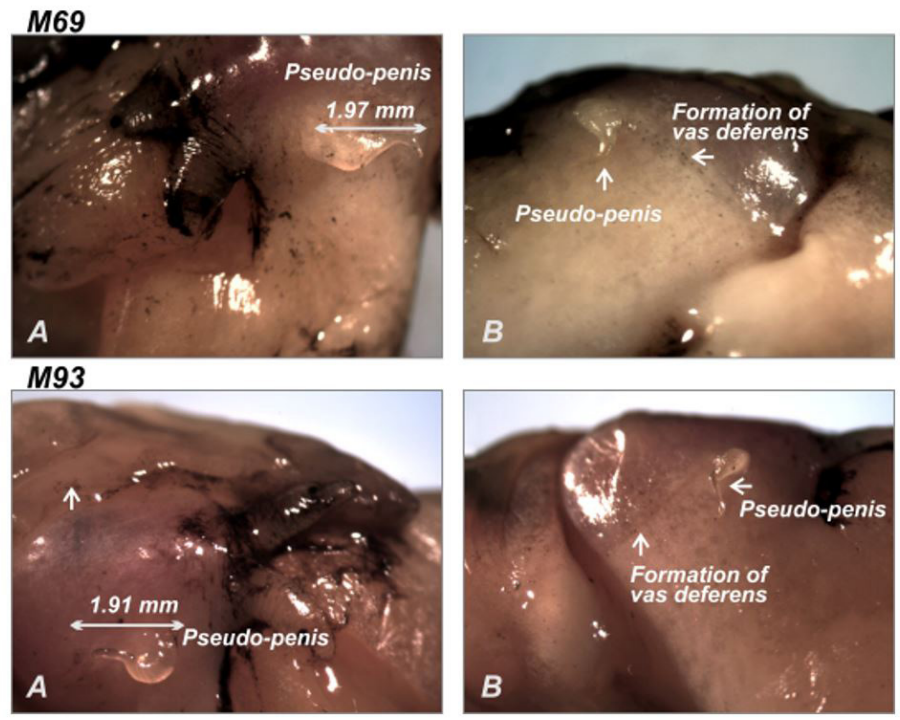

Figure 4. Representative images of the pseudo-penis present in female specimens in Stramonita haemastoma. (A, B) distinct photos from the same sample.

A

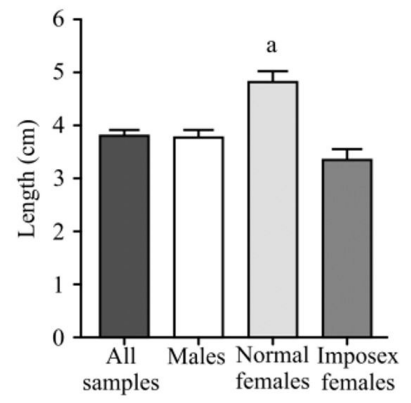

B

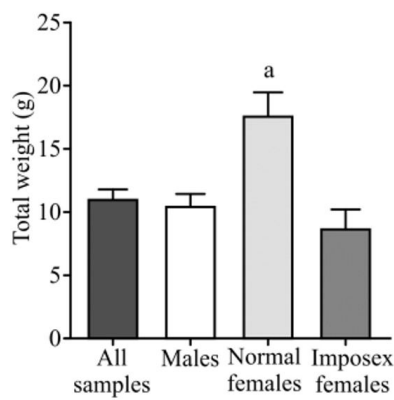

C

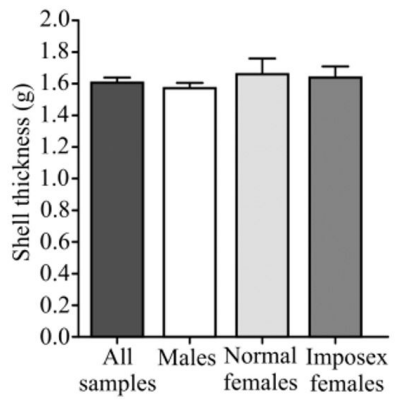

Figure 5. Morphometric variables in sampled snails according to sex and presence of imposex. (A) Shell length; (B) Total weight; (C) Shell thickness. a: Statistically significant different from the other groups $(\mathrm{P}<0.05)$. 


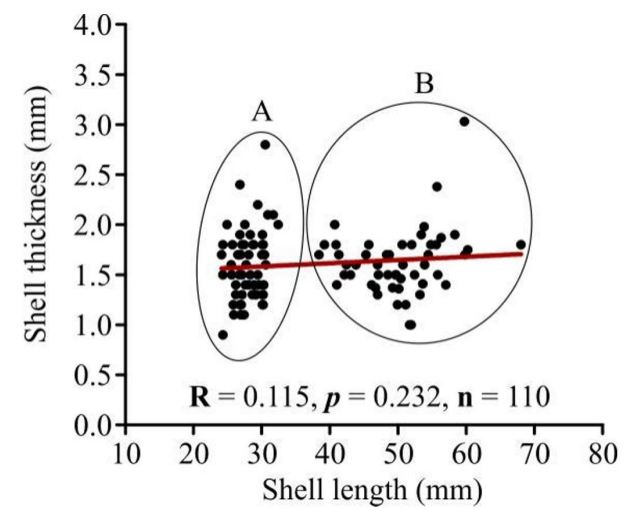

Figure 6. Shell length thickness for sampled snails. The regression line is shown only for description purposes. (A) Birds' Island; (B) La Bocana.

\section{Normal shell}

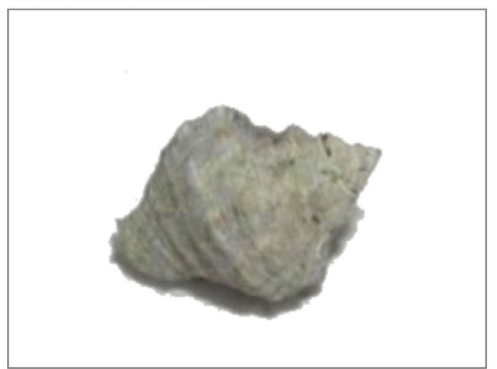

M55

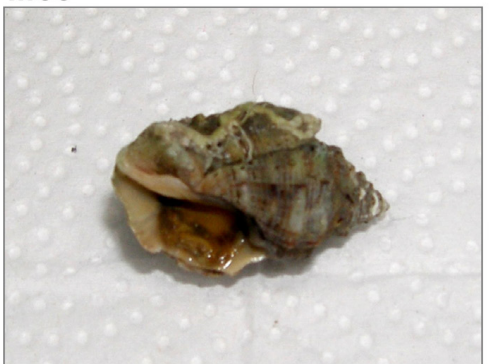

The relationship between SL and ST for examined specimens is shown in Figure 6. In general, the size of the specimens did not correlate with the thickness of the shell. However, two groups are clearly visible on the plot. They have different size ranges, the one on the left, Bird's Island, with a range on shell length from 241 to $324 \mathrm{~mm}$; and the one on the right, La Bocana, with values from 384 to $680 \mathrm{~mm}$, respectively.

Most snail shells from Cartagena Bay showed defects, cracks, rotting carcasses, and absence of sharp protrusions (Figure 7), which suggest that imposexed snails found in both places are experiencing malformations in the shell. The images clearly depict several of these features (M50, M55 and M56). Moreover, the concentrations of metals, evaluated by ICP-MS, found in shells of S. haemastoma from Bird's Island, compared to those reported for other snails around the world, are shown in Table 4.

\section{M50}

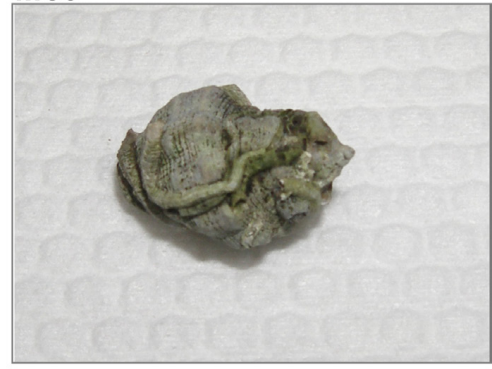

M56

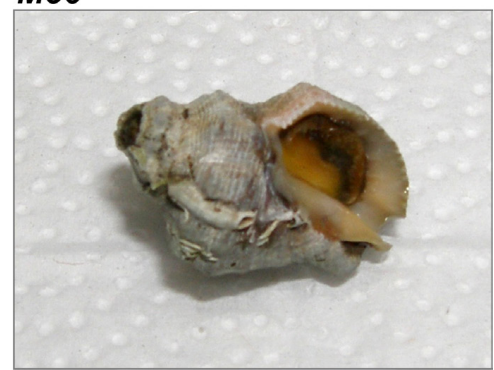

Figure 7. Typical shells of S. haemastoma specimens sampled in Cartagena Bay. Normal shell and samples with some deformities (M50, M55 and M56).

Table 4. Comparison of trace elements in S. haemastoma shells with those reported for other species.

\begin{tabular}{|c|c|c|c|c|c|c|c|c|c|c|}
\hline \multirow{2}{*}{ Species } & \multirow{2}{*}{ Country } & \multicolumn{8}{|c|}{ Element } & \multirow{2}{*}{ Source } \\
\hline & & $\mathrm{Cr}$ & $\mathrm{Ni}$ & $\mathrm{Cu}$ & Zn & As & Cd & Sn & $\mathbf{P b}$ & \\
\hline $\begin{array}{c}\text { Nerita } \\
\text { crepidularia }\end{array}$ & India & - & $\begin{array}{l}2.44- \\
14.58\end{array}$ & - & - & - & $\begin{array}{c}0.34- \\
0.76\end{array}$ & - & $0-0.22$ & $\begin{array}{c}\text { Palpandi and } \\
\text { Kesavan (2012) }\end{array}$ \\
\hline Brotia costula & Malaysia & - & - & $\begin{array}{c}10.67- \\
11.67\end{array}$ & $\begin{array}{l}30.17- \\
46.83\end{array}$ & $\begin{array}{l}43.50- \\
331.67\end{array}$ & - & - & - & $\begin{array}{l}\text { Lau et al. } \\
\text { (1998) }\end{array}$ \\
\hline $\begin{array}{l}\text { Melanoides } \\
\text { tuberculata }\end{array}$ & Malaysia & - & - & $\begin{array}{c}42.83- \\
108.3\end{array}$ & $\begin{array}{l}135.0- \\
215.0\end{array}$ & $\begin{array}{l}220- \\
1940\end{array}$ & $\begin{array}{l}6.0- \\
7.17\end{array}$ & - & $\begin{array}{c}2.50- \\
9.0\end{array}$ & $\begin{array}{l}\text { Lau et al. } \\
\text { (1998) }\end{array}$ \\
\hline $\begin{array}{l}\text { Cerithidea } \\
\text { cingulata }\end{array}$ & India & - & - & $\begin{array}{c}0.102- \\
0.840\end{array}$ & $\begin{array}{c}0.993- \\
1.766\end{array}$ & - & $\begin{array}{c}0.006- \\
0.099\end{array}$ & - & $\begin{array}{c}0.051- \\
0.070\end{array}$ & $\begin{array}{l}\text { Kesavan et al. } \\
\qquad(2013)\end{array}$ \\
\hline $\begin{array}{l}\text { Indothais } \\
\text { gradata }\end{array}$ & Brunei & 1.69 & 2.28 & 38.28 & 16.56 & - & 0.45 & - & 181.29 & $\begin{array}{l}\text { Proum et al. } \\
\qquad(2016)\end{array}$ \\
\hline S. haemastoma & Colombia & 0.056 & $<0.01$ & 0.880 & 0.479 & 0.158 & 0.02 & 0.126 & 0.695 & This study \\
\hline
\end{tabular}

-: No data available. 


\section{Discussion}

The morphometric characteristics and presence of imposex were evaluated in S. haemastoma collected at two places in Cartagena, Colombia. Morphometric variables are important to identify issues related to the physiological conditions or the degree of well-being for specific organisms, being useful for explaining the effects that environmental conditions may have on the sampled species (Perdomo et al., 2012). Although specimens of $S$. haemastoma can have sizes up to $9 \mathrm{~cm}$ in total length (CSIC, 2013), our measurements found an average size of $2.79 \pm 0.19 \mathrm{~cm}$ and $5.01 \pm 0.61 \mathrm{~cm}$ on specimens collected from the Birds' Island and La Bocana, respectively. This may suggest specimens collected in Birds' Island did not mature sufficiently, probably as a result of pollutant exposure.

Imposexed females were documented in both sampling sites. The highest frequency was detected in specimens from Birds' Island, indicating that this species is a reliable indicator of pollution from organotin compounds, mostly arising from paint from boats (Paz-Villarraga et al., 2015). Moreover, females from Birds' Island have also the highest levels of imposex (Level 2), suggesting the female population of this species at this site could have a low reproductive capacity in the future (Fernández et al., 2002).

Several authors have reported that several mollusk species are susceptible to the development of imposex (Spence et al., 1990; Castro et al., 2000; Fernández et al., 2002; Lima et al., 2006; Toste et al., 2013). Some of those studies have linked the extent of the imposex level detected in specimens from Birds' Island to adverse effects such as low reproductive capacity or even complete sterility, affecting its health and survival capacity (Fernández et al., 2002). Although this is the first report for Cartagena, North of Colombia, imposex-related studies have also been documented for several species in other geographic locations in South America, including Brazil (Zeidan and Boehs, 2016; Fernández et al., 2002), Venezuela (Paz-Villarraga et al., 2015) and Ecuador (Castro et al., 2012).

Many other organisms besides snails can experience endocrine disruption (Graceli et al., 2013; Zhang et al., 2013). It has been reported there is a health risk related to organotin exposure in mammalian species (Zuo et al., 2011). These organometallic chemicals, in particular TBT, the organotin chemical linked to imposex, accumulate primarily in fetal tissues, eventually leading to an impaired role of sexual enzymes and normal fetal development. Moreover, it has also been associated with obesity in mice (Graceli et al., 2013). This effect is important during the differentiation of adipocytes; the activation of proteins and receptors related to fat storage (Kirchner et al., 2010); and the imbalance of chemokines, interleukins, leptin (Carfi et al., 2008), and insulin (Zuo et al., 2011).

The literature describes in vivo studies demonstrating that $S$. haemastoma developed imposex characteristics when ingesting food sources contaminated with organotin compounds (Lima et al., 2006). This species is capable of storing this chemical in their bodies. In fact, samples of
S. haemastoma collected in Brazil showed higher values for RPLI and RPSI indexes in the contaminated area (Fernández et al., 2005). However, the indexes related to pseudo-penis size, may also vary according to the species (Fernández et al., 2002) and the season (Titley-O'Neal et al., 2011; Graceli et al., 2013).

Some authors have argued that the presence of TBT compounds in seawater can induce certain types of malformations. Alzieu (1986) characterized the abnormal formation of the shell on oysters exposed to these types of compounds. Samples collected from Birds' Island clearly display both malformation and wear of shell. These specimens also had the same level of imposex (grade 2), suggesting some degree of relationship between the occurrence of imposex and the poor state of the shell. On the other hand, endocrine disruption is not likely related to high concentrations of heavy metals deposited in the shell, as most toxic elements appear at low levels compared to other studies (See Table 4).

The results suggest the prevalence of imposex and malformations observed on S. haemastoma from the Birds' Island in Cartagena are a clear biomarker of exposure and biological effects caused by TBT in coastal areas associated with high influence of maritime activities (Fernández et al., 2005; Toste et al., 2013; Lima et al., 2006). New studies should include TBT and hormone levels in snails, as well as the quantification of these chemicals in water and sediments.

\section{Acknowledgements}

The authors thank the Program to Support Research Groups, sponsored by the Vice-Presidency for Research at the University of Cartagena, Program to Support Research Groups (2013-2014), UniCartagena 047-2017. We would like to thank Alejandra Manjarres (UniCartagena) and Chelsea Hundley (Purdue University, Indiana, USA) for her technical assistance. The National Program supports Lucellys Sierra for Doctoral Formation (Colciencias, 647-2014), Bogota, and the University of Cartagena.

\section{References}

ALZIEU, C., 1986. TBT detrimental effects on oyster culture in France: evolution since antifouling paint regulations. Oceans, vol. 86, pp. 1130-1134.

BAI, X., XIE, G., FAN, H., PENG, Z., YUAN, C. and YAN, X., 2013. Study on biomimetic preparation of shell surface microstructure for ship antifouling. Wear, vol. 306, no. 1-2, pp. 285-295. http://dx.doi.org/10.1016/j.wear.2012.11.020.

CARFI, M., CROERA, C., FERRARIO, D., CAMPI, V., BOWE, G., PIETERS, R. and GRIBALDO, L., 2008. TBTC induces adipocyte differentiation in human bone marrow long term culture. Toxicology, vol. 249, no. 1, pp. 11-18. PMid:18501494. http:// dx.doi.org/10.1016/j.tox.2008.03.025.

CASTRO, I.B., ARROYO, M.F., COSTA, P.G. and FILLMANN, G., 2012. Butyltin compounds and imposex levels in Ecuador. Archives of Environmental Contamination and Toxicology, vol. 
62, no. 1, pp. 68-77. PMid:21503701. http://dx.doi.org/10.1007/ s00244-011-9670-2.

CASTRO, I.B., CASCON, H. and FERNÁNDEZ, M., 2000. Imposex em Thais haemastoma (Linnaeus, 1767) (Mollusca: Gastropoda), uma indicação da contaminação por organoestânicos na costa do município de Fortaleza-Ceará - Brasil. Arquivos de Ciências do Mar, vol. 33, pp. 51-56.

CONSEJO SUPERIOR DE INVESTIGACIONES CIENTÍFICAS - CSIC, 2013 [viewed November 2016]. Terminology databases and identification of fish species from the coast of Andalucia [online]. Madrid. Available from: http://www.ictioterm.es/ nombre_cientifico.php?nc=289

DEPARTAMENTO ADMINISTRATIVO NACIONAL DE ESTADÍSTICA - DANE, 2010 [viewed 30 September 2016]. Demografia y población: proyecciones de población [online]. Available from: https://www.dane.gov.co/index.php/estadisticaspor-tema/demografia-y-poblacion/proyecciones-de-poblacion

FERNÁNDEZ, M.A., LIMAVERDE, A.M., CASTRO, I.B., ALMEIDA, A.C. and WAGENER, A.L.R., 2002. Occurrence of imposex in Thais haemastoma: possible evidence of environmental contamination derived from organotin compounds in Rio de Janeiro and Fortaleza, Brazil. Cadernos de Saude Publica, vol. 18, no. 2, pp. 463-476. PMid:11923888. http://dx.doi.org/10.1590/ S0102-311X2002000200011.

FERNÁNDEZ, M.A., WAGENER, A.L.R., LIMAVERDE, A.M., SCOFIELD, A.L., PINHEIRO, F.M. and RODRIGUES, E., 2005. Imposex and surface sediment speciation: A combined approach to evaluate organotin contamination in Guanabara Bay, Rio de Janeiro, Brazil. Marine Environmental Research, vol. 59, no. 5, pp. 435-452. PMid:15603768. http://dx.doi.org/10.1016/j. marenvres.2004.07.001

FURDEK, M., VAHČIČ, M., ŠČANČAR, J., MILAČIČ, R., KNIEWALD, G. and MIKAC, N., 2012. Organotin compounds in seawater and Mytilus galloprovincialis mussels along the Croatian Adriatic Coast. Marine Pollution Bulletin, vol. 64, no. 2, pp. 189-199. PMid:22225913. http://dx.doi.org/10.1016/j. marpolbul.2011.12.009.

GAVIO, B., PALMER-CANTILLO, S. and MANCERA, J., 2010. Historical analysis (2000-2005) of the coastal water quality in San Andrés Island, SeaFlower Biosphere Reserve, Caribbean Colombia. Marine Pollution Bulletin, vol. 60, no. 7, pp. 1018-1030. PMid:20219216. http://dx.doi.org/10.1016/j. marpolbul.2010.01.025.

GIBBS, P.E. and BRYAN, G., 1987. TBT paints and demise of the dog-whelk, Nucella lapillus, (Gastropoda). Oceans, vol. 87, pp. 1482-1487.

GIBBS, P. and BRYAN, G., 1994. Biomonitoring of tributyltin (TBT) pollution using the imposex response of neogastropod molluscs. In: K. KRAMER, ed. Biomonitoring of coastal waters and estuaries. Boca Raton: CRC Press, pp. 205-226. vol. 54.

GIUSTI, A. and JOAQUIM-JUSTO, C., 2013. Esterification of vertebrate like steroids in molluscs: a target of endocrine disruptors? Comparative Biochemistry and Physiology Part C: Toxicology and Pharmacology, vol. 158, no. 4, pp. 187-198. http://dx.doi. org/10.1016/j.cbpc.2013.08.003. PMid:24004916.

GRACELI, J.B., SENA, G.C., LOPES, P.F., ZAMPROGNO, G.C., DA COSTA, M.B., GODOI, A.F., DOS SANTOS, D.M., DE MARCHI, M.R. and DOS SANTOS-FERNANDEZ, M.A., 2013. Organotins: a review of their reproductive toxicity, biochemistry, and environmental fate. Reproductive Toxicology (Elmsford, N.Y.), vol. 36, pp. 40-52. PMid:23228341. http://dx.doi.org/10.1016/j. reprotox.2012.11.008

HALEM, Z.M., ROSS, D.J. and COX, R.L., 2014. Evidence for intraspecific endocrine disruption of Geukensia demissa (Atlantic ribbed mussel) in an urban watershed. Comparative Biochemistry and Physiology. Part A, Molecular \& Integrative Physiology, vol. 175, pp. 1-6. PMid:24813673. http://dx.doi.org/10.1016/j. cbpa.2014.04.016.

JOHNSON-RESTREPO, B., OLIVERO-VERBEL, J., LU, S., GUETTE-FERNANDEZ, J., BALDIRIS-AVILA, R., O'BYRNEHOYOS, I., ALDOUS, K.M., ADDINK, R. and KANNAN, K., 2008. Polycyclic aromatic hydrocarbons and their hydroxylated metabolites in fish bile and sediments from coastal waters of Colombia. Environmental Pollution, vol. 151, no. 3, pp. 452-459. PMid:17555855. http://dx.doi.org/10.1016/j.envpol.2007.04.011.

KESAVAN, K., MURUGAN, A., VENKATESAN, V. and VIJAY KUMAR, B.S., 2013. Heavy metal accumulation in molluscs and sediment from Uppanar Estuary, Southeast Coast of India. Thalassas, vol. 29, no. 2, pp. 15-21.

KIRCHNER, S., KIEU, T., CHOW, C., CASEY, S. and BLUMBERG, B., 2010. Prenatal exposure to the environmental obesogen tributyltin predisposes multipotent stem cells to become adipocytes. Molecular Endocrinology (Baltimore, Md.), vol. 24, no. 3, pp. 526-539. PMid:20160124. http://dx.doi.org/10.1210/ me.2009-0261

LAU, S., MOHAMED, M., YEN, A.T. and SU'UT, S., 1998. Accumulation of heavy metals in freshwater molluscs. The Science of the Total Environment, vol. 214, no. 1, pp. 113-121. PMid:9646520. http://dx.doi.org/10.1016/S0048-9697(98)00058-8.

LIMA, A.F.A., CASTRO, I.B. and ROCHA-BARREIRA, C.A., 2006. Imposex induction in Stramonita haemastoma floridana (Conrad, 1837) (Mollusca: Gastropoda: Muricidae) submitted to an organotin-contaminated diet. Brazilian Journal of Oceanography, vol. 54, no. 1, pp. 85-90. http://dx.doi.org/10.1590/S167987592006000100008

PALPANDI, C. and KESAVAN, K., 2012. Heavy metal monitoring using Nerita crepidularia-mangrove mollusc from the Vellar estuary, Southeast coast of India. Asian Pacific Journal of Tropical Biomedicine, vol. 2, no. 1, pp. S358-S367. http://dx.doi. org/10.1016/S2221-1691(12)60188-9.

PAZ-VILLARRAGA, C.A., CASTRO, I.B., MILOSLAVICH, P. and FILLMANN, G., 2015. Venezuelan Caribbean Sea under the threat of TBT. Chemosphere, vol. 119, pp. 704-710. PMid:25155631. http://dx.doi.org/10.1016/j.chemosphere.2014.07.068.

PERDOMO, D.A., CORREDOR, Z. and RAMIREZ-IGLESIA, L., 2012. Características físico-químicas y morfométricas en la crianza por fases de la tilapia roja (Oreochromis spp) en una zona cálida tropical. Zootecnia Tropical, vol. 30, no. 1, pp. 99-108.

PETRO, E., LEROY, J., VAN CRUCHTEN, S., COVACI, A., JORSSEN, E. and BOLS, P., 2012. Endocrine disruptors and female fertility: Focus on (bovine) ovarian follicular physiology. Theriogenology, vol. 78, no. 9, pp. 1887-1900. PMid:22925646. http://dx.doi.org/10.1016/j.theriogenology.2012.06.011.

PROUM, S., SANTOS, J.H., LIM, L.H. and MARSHALL, D.J., 2016. Metal accumulation in the tissues and shells of Indothais gradata snails inhabiting soft and hard substrata in an acidified tropical estuary (Brunei, South East Asia). Regional Studies in Marine Science, vol. 8, pp. 487-497. http://dx.doi.org/10.1016/j. rsma.2016.03.010 
RADKE, B., WASIK, A., JEWELL, L., PIKETH, S., PACZZEK, U., GAŁUSZKA, A. and NAMIEŚNIK, J., 2012. Seasonal changes in organotin compounds in water and sediment samples from the semi-closed Port of Gdynia. The Science of the Total Environment, vol. 441, pp. 57-66. PMid:23134769. http://dx.doi. org/10.1016/j.scitotenv.2012.09.006.

SPENCE, S., HAWKINS, S. and SANTOS, R., 1990. The mollusk Thais haemastoma an exhibitor of 'Imposex' and potential biological indicator of tributyltin pollution. Marine Ecology (Berlin), vol. 11, no. 2, pp. 147-156. http://dx.doi.org/10.1111/j.1439-0485.1990. tb00235.x.

STATGRAPHICS TECHNOLOGIES. Statgraphics Centurion 15.1.0.2: demo version. Warrenton, 2013.

TITLEY-O'NEAL, C., MUNKITTRICK, K. and MACDONALD, B., 2011. The effects of organotin on female gastropods. Journal of Environmental Monitoring, vol. 13, no. 9, pp. 2360-2388. PMid:21826318. http://dx.doi.org/10.1039/c1em10011d.

TOSTE, R., PESSOA, I.A., DORE, M.P., PARAHYBA, M.A. and FERNÁNDEZ, M.A., 2013. Is aphallic vas deferens development in females related to the distance from organotin sources? A study with Stramonita haemastoma. Ecotoxicology and Environmental
Safety, vol. 91, pp. 162-170. PMid:23485038. http://dx.doi. org/10.1016/j.ecoenv.2013.01.026.

VERHAEGEN, Y., MONTEYNE, E., NEUDECKER, T., TULP, I., SMAGGHE, G., COOREMAN, K., ROOSE, P. and PARMENTIER, K., 2012. Organotins in North Sea brown shrimp (Crangon crangon L.) after implementation of the TBT ban. Chemosphere, vol. 86, no. 10, pp. 979-984. PMid:22154339. http://dx.doi.org/10.1016/j. chemosphere.2011.11.028.

ZEIDAN, G.C. and BOEHS, G., 2016. Assessment of tributyltin contamination based on imposex in Stramonita rustica (Mollusca: Gastropoda) along southern Bahia coast, northeastern Brazil. Brazilian Journal of Biology = Revista Brasileira de Biologia . http://dx.doi.org/10.1590/1519-6984.15115. PMid:27533729.

ZHANG, J., ZUO, Z., XIONG, J., SUN, P., CHEN, Y. and WANG, C., 2013. Tributyltin exposure causes lipotoxicity responses in the ovaries of rockfish, Sebastiscus marmoratus. Chemosphere, vol. 90, no. 3, pp. 1294-1299. PMid:23153777. http://dx.doi. org/10.1016/j.chemosphere.2012.10.078.

ZUO, Z., CHEN, S., WU, T., ZHANG, J., SU, Y., CHEN, Y. and WANG, C., 2011. Tributyltin causes obesity and hepatic steatosis in male mice. Environmental Toxicology, vol. 26, no. 1, pp. 79-85. PMid:19760618. http://dx.doi.org/10.1002/tox.20531. 